\title{
Facts About Citrus Fruits and Juices: Grapefruit ${ }^{1}$
}

Gail C. Rampersaud $^{2}$

Grapefruit is a medium- to large-sized citrus fruit. It is larger than most oranges and the fruit may be flattened at both ends. The skin is mostly yellow but may include shades of green, white, or pink. Skin color is not a sign of ripeness. Grapefruit are fully ripe when picked.



\section{Did you know...}

- Grapefruit was first discovered in the West Indies and introduced to Florida in the 1820s. Most grapefruit in the U.S. is still grown in Florida.

- Grapefruit got its name because it grows in clusters on the tree, just like grapes!

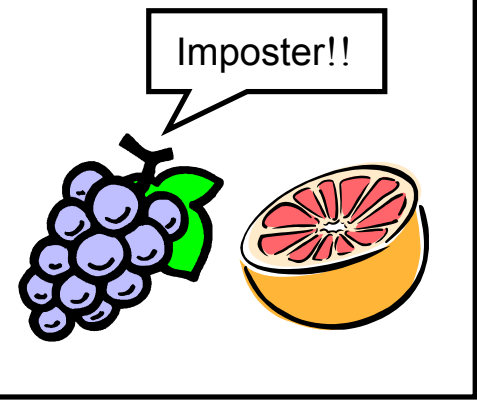

Popular varieties of Florida grapefruit include:

* Marsh White - white to amber colored flesh and almost seedless.

* Ruby Red - pink to reddish colored flesh with few seeds.

* Flame - red flesh and mostly seedless.



Compared to most citrus fruits, grapefruit have an extended growing season and several Florida varieties grow from September through June.

Fresh citrus can be stored in any cool, dry place but will last longer if stored in the refrigerator. Do not store fresh grapefruit in plastic bags or filmwrapped trays since this may cause mold to grow on the fruit.

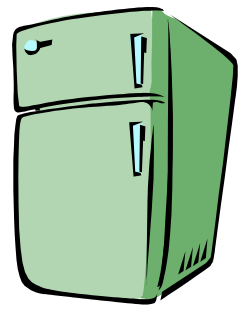

Whether you choose white or pink grapefruit or grapefruit juice, you'll get great taste and a variety of health benefits! Read on....

1. This document is FSHN026, one of a series of the Food Science and Human Nutrition Department, Florida Cooperative Extension Service, Institute of Food and Agricultural Sciences, University of Florida. Publication: September 2002. Reviewed by: R.E. Turner, Ph.D., associate professor; and G.P. Kauwell, Ph.D. associate professor, both of the Food Science and Human Nutrition Department, Cooperative Extension Service, Institute of Food and Agricultural Sciences, University of Florida, Gainesville, FL 32611-0370. Please visit the EDIS Web Site at http://edis.ifas.ufl.edu.

2. G.C. Rampersaud, M.S., assistant in, Food Science and Human Nutrition Department, Cooperative Extension Service, Institute of Food and Agricultural Sciences, University of Florida, Gainesville, FL 32611-0370. 
Grapefruit and grapefruit juice are great-tasting natural foods that have many health benefits! In fact, half of a medium, fresh pink Florida grapefruit provides:

$\checkmark 60$ calories

$\checkmark 100 \%$ or more of the Daily Value for vitamin C

$\checkmark$ Other important vitamins and minerals such as potassium, vitamin $\mathrm{A}$, folate, thiamin, niacin, and magnesium

$\checkmark$ Fiber (grapefruit juice is not a significant source of fiber)

$\checkmark$ Phytochemicals, such as lycopene, that are thought to reduce the risk for chronic diseases like cancer

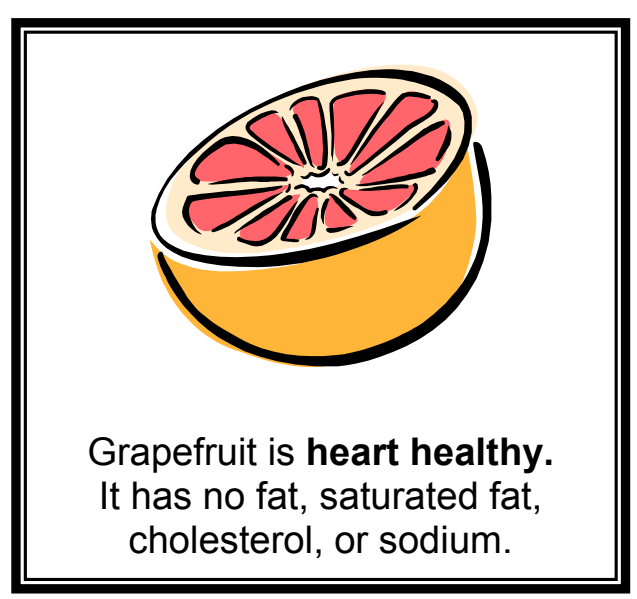

$\checkmark$ Calcium (especially in calcium-fortified grapefruit juice)

Here are ways to boost your daily fruit intake using grapefruit or grapefruit juice!

Eat $1 / 2$ grapefruit with breakfast or lunch, or as a snack.

Drink a glass of grapefruit juice with breakfast or as a snack.

Cut grapefruit into segments and use as a topping on cereal, waffles or pancakes.

- Put grapefruit segments on toothpicks to create a fun snack for kids.

Mix grapefruit juice with club soda for a refreshing drink.

Try a refreshing vitamin Cpacked shake or smoothie made with grapefruit juice!

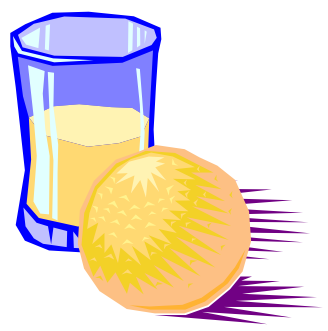

\section{Florida Sunshine Shake}

1cup Florida orange juice

$1 / 2$ cup Florida grapefruit juice

1 ripe banana

$1 / 2$ cup low-fat vanilla yogurt

$1 / 2$ teaspoon vanilla extract

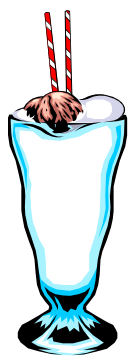

Combine all ingredients in blender until smooth.

Pour into glass, and serve immediately. Makes two 8-ounce servings.

NUTRITION TIP: Use calcium-fortified orange and grapefruit juice to increase calcium intake!

NUTRITION FACTS PER SERVING: 190 calories, $5 \mathrm{~g}$ protein, $40 \mathrm{~g}$ carbohydrate, $1 \mathrm{~g}$ fat ( $0.5 \mathrm{~g}$ saturated fat), $60 \mathrm{mg}$ vitamin $\mathrm{C}, 650 \mathrm{mg}$ potassium, $40 \mathrm{mg}$ sodium, $2 \mathrm{~g}$ fiber.

Recipe courtesy of the Florida Department of Citrus.

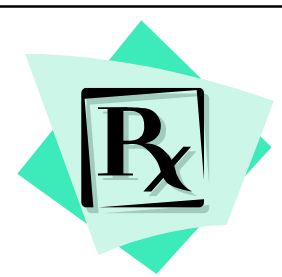

\section{Grapefruit Juice and Medications}

Certain cholesterol-lowering, blood pressure, and antihistamine prescription medications may interact with grapefruit juice. However, most medications are not affected. Speak with your doctor or pharmacist if you are concerned about whether your medications may be affected by grapefruit juice. 